\title{
Novel food legislation and consumer acceptance - Importance for the food industry
}

\author{
Nada Knežević1*, Slavka Grbavac ${ }^{1}$, Marina Palfi', Marija Badanjak Sabolovićé, Suzana Rimac Brnčić ${ }^{2}$ \\ ${ }^{1}$ Research and Development, Podravka Ltd., Ante Starčevića 32, 48000 Koprivnica, Croatia, ${ }^{2}$ Faculty of Food Technology and Biotechnology, \\ University of Zagreb, 10000 Zagreb, Croatia
}

\section{A B S TR A C T}

\begin{abstract}
Novel foods are defined as foods and food ingredients that have not yet been used to any significant extent in a given country. This paper provides a brief overview of current novel food legislation in European Union, USA, Australia and New Zealand, Canada and China. Prior to sale, food business operators (manufacturers or importers) are required, by different regulations and procedures, to submit information about the product in question for a safety assessment to Food Safety Authority. The approaches and specific information for evaluating the safety of novel foods are described in the national guidelines. In general, for the safety assessment and marketing authorisation of a novel food, the applicant should provide a detailed description of the novel food (identity of the novel food, manufacturing process, compositional data, proposed uses and use levels and anticipated intake of the novel food, history of use of the novel food and/or its source, absorption, distribution, metabolism and excretion, nutritional information, toxicological information and allergenicity).
\end{abstract}

Keywords: Food business operators; Legislation; Novel food; Safety assessment.

\section{INTRODUCTION}

Food today is intended not only to satisfy hunger and provide people with necessary nutrients, but also to prevent diet-related diseases and improve the physical and mental well-being of consumers. Advances in food science, technology and production have greatly reduced diseases caused by nutrient deficiencies, at the same time we face growing challenges such as uncontrolled food intake, obesity, non-infectious diseases and aging (Shao et al., 2017; Adams et al., 2019). Dietary habits and the nutritional value of foods consumed with regular meals play a key role in preventing major chronic degenerative diseases (Kant, 2010). As concern for one's health increases with a better knowledge of the nutritional value of food, modern consumers are becoming more discerning about food consumption. In order to meet the needs of consumers and to be competitive in the global food market, the food industry is one of the main drivers of innovative and new products and technologies (De Roos et al., 2019). Moreover, the globalization of food supply, the movement of goods and services is becoming faster and faster, so that foods are entering the market that were not previously available and consumed in a particular country or region. Novel foods fall into the category of foods that are considered potentially hazardous to public health because of the new, unknown ingredients they contain. Although it is almost impossible to ensure that a food will never pose a risk to a consumer (Blaauboer et al., 2016).

There are a growing number of studies related to the possible sources of novel food and its nutritional and sensory properties (Kaur et al., 2018; House; 2019; Zarbà et al., 2020). Novel food and novel food sources have encouraged interest of the scientific community, producers and consumers to the development of new and innovative products and technologies, as well as research into possible health benefits and / or risks (Knežević et. al, 2012; Caporgno and Mathys, 2018; Majid et al. 2018; Mazzucchelli et al, 2018; Cappelli et al., 2020; Abdelmoteleb et al., 2021).

The results of research related to novel food emphasizing the importance of proper information to consumers using appropriate tools and communication strategies that can contribute to greater motivation and raising consumer awareness about the benefits of novel food (Laureati

\footnotetext{
*Corresponding author:

Nada Knežević, Research and Development, Podravka Ltd., Ante Starčevića 32, 48000 Koprivnica, Croatia.

E-mail: nada.knezevic@podravka.hr
} 
et al., 2016; Martini et al., 2019). Novel foods must be properly labeled so as not to mislead consumers. Providing consumers with clear and complete information is key to informing consumers about the characteristics and exact nature of a food product. Consumers should pay special attention to reading labels to be informed whether the product is suitable for them (Baraniak et al., 2016, Martini et al., 2019). The European Union legal framework (Novel Food Regulation (NFR) 2283/2015) ensures that consumers are protected as much as possible from unsafe products (Regulation (EU) 2015/2283). The scientific risk assessment and communication of risks associated with new foods in Europe carried out by the European Food Safety Authority (EFSA). It is important to emphasize that the heterogeneous nature and changing complexity of novel foods is a major challenge in determining the approach to assessing the characteristics of each individual product, and further joint action by all stakeholders in EFSA's risk assessment process is needed (Ververis et al., 2020).

The aim of this paper is to give a brief overview of current of current legislation of novel food in the European Union, the United Kingdom, the United States, Australia and New Zealand, Canada, and China. The paper describes the requirements that food business operators / applicants in the EU have to submit to the Food Safety Authority about the product in question for safety assessment and shows examples of approved novel foods in the EU and consumer opinions about novel foods.

\section{LEGISLATION}

In the EU, the first novel foods regulation came into force in (1997) Regulation (EC) No 258/97 about novel foods and the ingredients of novel foods. The European Union Novel Foods Regulation applies to foods and food ingredients that have not been used for human consumption to a significant degree within the European Community before May 15, 1997.

The new Regulation of the European Parliament and of the Council (EU) 2015/2283, which replaces the previous Regulation, entered into force on 1 January 2018 (Regulation (EU) 2015/2283). The new Regulation was adopted to avoid differences between national rules for the authorisation of safety assessment and the authorisation of novel foods, to clarify the definition of novel foods, to update the categories of novel foods, to update the list of novel foods authorised for placing on the market in the European Union, simplify and take into account recent changes in Union law and technological progress, clearly define and establish the criteria for the assessment of safety risks associated with novel foods in order to facilitate the placing on the Union market of traditional foods from third countries where the safe use of foods in a third country has been demonstrated in the past. New submissions go directly to the Commission. Submissions must be prepared in accordance with the new specific submission rules and guidance European Food Safety Authority (EFSA). The decision of European Commission (EC) to authorize the placing on the market of a novel food product or food ingredient is based on the risk assessment carried out by European Food Safety Authority (EFSA). As part of this risk assessment, EFSA examines the dossier submitted by the food business operator seeking authorisation for its product, which assesses the health risks of the product. All applications under the NFR must include scientific data demonstrating the safety of NF for human consumption. If the application is complete, EFSA adopts its opinion within nine months of receiving a valid application. There is also a separate notification with procedures for "traditional foods from third countries" in line with the requirements of Article 14 of the new Regulation.

Traditional foods are foods or food ingredients derived from primary production whose use in the customary diet of a significant number of people in at least one country outside the EU has been confirmed by compositional data and experience of continuous use over at least 25 years. The notification procedure for traditional foods is simplified. The Member State or the Authority may, within 4 months, submit to the Commission duly substantiated safety objections to the placing on the market in the Union.

In assessing the safety of novel foods, EFSA shall consider whether the novel food is as safe as foods of a comparable category already placed on the market in the Union and whether the composition and conditions of use of the novel food present a risk to human health. Together with the harmonization of legislation in the European Union, one of the objectives of this act was to ensure that novel products are safe for the health of consumers by stipulating that "food shall not be placed on the market if it is not safe" (de Boer and Bast, 2018).

Regulation (EU) 2015/2283 improved the conditions under which food businesses can easily place new and innovative foods on the market, provided that they ensure a high standard of food safety for consumers. Novel foods must be safe for consumers and properly labelled so as not to mislead consumers. Where a novel food is intended to replace another food, it must not differ in such a way that the consumption of the novel food would be nutritionally disadvantageous for the consumer.

All novel foods that have EU authorization are included in a Union List of Novel Foods. It contains information about different foods and food ingredients concerning for their 
novel food status (Regulation (EU) 2015/2283; European Commission, 2020). The Union List of Novel Foods contains information on all approved ingredients and their conditions of use (specified food category and maximum levels), labelling requirements and their specifications. The extended list of novel food categories, according to the new Regulation, is presented in Table 1.

According to Article 4 of Novel Food Regulation (EU) $2015 / 2283$, food business operators must verify whether

Table 1: Regulation of Novel food in European Union (Source: Regulation (EU) 258/97; 2015/2283;)

\begin{tabular}{|c|c|}
\hline & Regulation \\
\hline$E U$ & 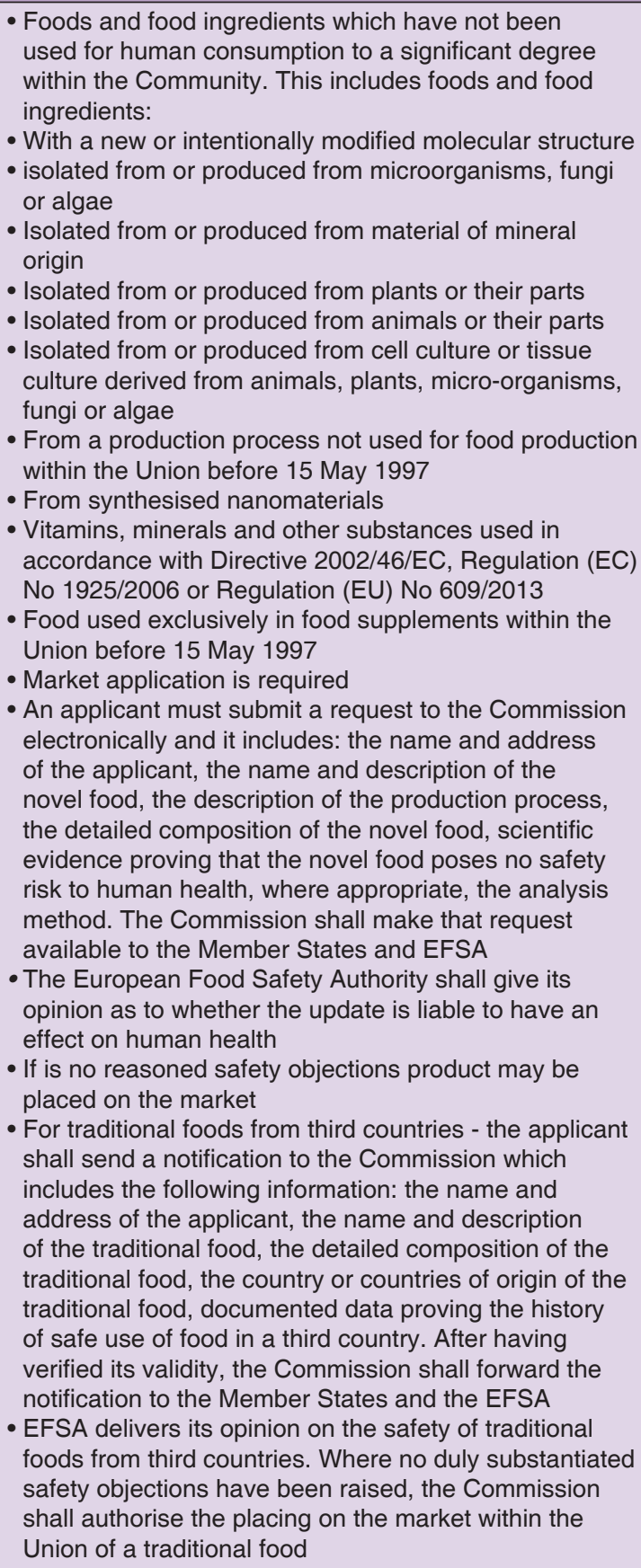 \\
\hline
\end{tabular}

the food they intend to place on the European Union (EU) market falls within the scope of the Novel Food Regulation. (Regulation (EU) 2015/2283). Where food business operators are unsure whether or not a food they intend to place on the Union market falls within the scope of Regulation (EU) 2015/2283, they shall consult the Member State in which they intend to place the novel food on the market. Food business operators shall provide the Member State with the necessary information to enable it to determine whether the food falls within the scope of Regulation (EU) 2015/2283. In order to determine whether a particular food falls within the scope of Regulation (EU) 2015/2283, Member States may consult other Member States and the Commission (Regulation (EU) 2015/2283). The Catalogue of foods listing products of animal and plant origin and other substances subject to the New Regulation (EU) 2015/2283, on Novel foods, on information provided by the Member States to the European Union (EU), is available on the website of the European Commission and will be regularly amended as new information is provided by the Member States (European Commission, 2020). 'The most recent examples of authorized novel foods are presented in Table 2.

In Great Britain, novel foods must be approved before they can be placed on the market. There are two approval routes under retained EU law for novel foods:The traditional food notification and the full application (Novel Foods authorisation guidance, 2020).

Although "novel foods" are not defined in the United States, any new food ingredient is considered either a food additive (which requires premarket approval by the U.S. Food and Drug Administration (FDA) or generally recognized as safe (GRAS) for certain uses, which may be determined by consensus of a panel of qualified experts. Novel foods in the States are either verified by the FDA or subjected to GRAS analysis. Under the requirements of GRAS, a food company must demonstrate that its "food additive" is GRAS before delivery. The food company must show that experts would agree that the substance GRAS under the conditions of its intended use in food is based on either scientific procedures or a history of use prior to 1958. Food businesses may hire a group of experts to evaluate the GRAS status of a substance. A food business is not required to notify FDA of its intent to sell a substance GRAS, but may do so if it wishes. Upon receipt of the GRAS notification, the USFDA will provide an indication of whether or not the basis of the GRAS decision appears appropriate (Magnuson et al., 2013; Food and Drug Administration, 2020; Overview of International Regulatory Approaches - Proposal P1024, 2020).

In Australia and New Zealand, novel foods and novel food ingredients are regulated under Standard 1.5.1 - Novel Foods 
Table 2: Examples of authorized novel foods in EU depending on categories (Source: European Commission, Union list of novel foods)

\begin{tabular}{|c|c|c|c|}
\hline Name & Categories of novel foods & Food category & $\begin{array}{l}\text { Commission } \\
\text { implementing regulation }\end{array}$ \\
\hline $\begin{array}{l}\text { Ecklonia cava } \\
\text { phlorotannins }\end{array}$ & $\begin{array}{l}\text { Food consisting of, isolated } \\
\text { from or produced from } \\
\text { microorganisms, fungi or } \\
\text { algae' }\end{array}$ & $\begin{array}{l}\text { Food Supplements as defined in Directive 2002/46/EC } \\
\text { intended for the general population, excluding children } \\
\text { under the age of } 12 \text { years }\end{array}$ & Decision (EU) 2018/460 \\
\hline L-ergothioneine & $\begin{array}{l}\text { Foods with a new or } \\
\text { intentionally modified } \\
\text { molecular structure }\end{array}$ & $\begin{array}{l}\text { Alcohol-free beverages, Milk-based drinks, 'Fresh' milk } \\
\text { products, Cereal bars, Chocolate confectionery, Food } \\
\text { supplements as defined in Directive 2002/46/EC }\end{array}$ & Decision (EU) 2018/462 \\
\hline $\begin{array}{l}\text { Vitamin D2 mushroom } \\
\text { powder }\end{array}$ & $\begin{array}{l}\text { Food } \\
\text { consisting of, isolated } \\
\text { from or produced from } \\
\text { microorganisms, fungi or } \\
\text { algae' }\end{array}$ & $\begin{array}{l}\text { Breakfast cereals, Yeast-leavened bread and pastries, } \\
\text { Grain products and pastas, Fruit juice and fruit/vegetable } \\
\text { blend Beverages, Milk and dairy products (excluding fluid } \\
\text { milks), Cheese (excluding cottage cheese, ricotta cheese, } \\
\text { and hard-grating cheeses), Meal replacement bars and } \\
\text { beverages, Dairy analogues, Meat analogues, Soups and } \\
\text { broths, Extruded vegetable snacks, Foods for Special } \\
\text { Medical Purposes as defined under Regulation (EU) } \\
\text { No } 609 / 2013 \text { excluding those intended for infants, Food } \\
\text { supplements as defined in Directive } 2002 / 46 / E C \text { intended } \\
\text { for the general population excluding infants }\end{array}$ & Decision (EU) 2020/1163 \\
\hline Lactoferrin & $\begin{array}{l}\text { Food consisting of, isolated } \\
\text { from or produced from } \\
\text { animal material }\end{array}$ & $\begin{array}{l}\text { Infant formulae and follow-on formulae (ready to drink), } \\
\text { Foods on dairy basis intended for young children (ready } \\
\text { to eat/drink, Processed cereal food (solid), Foods for } \\
\text { special medical purposes, Beverages based on milk, } \\
\text { Powdered drink mixes based on milk (ready to drink), } \\
\text { Beverages based on fermented milk (including yoghurt } \\
\text { drinks), Non-alcoholic drinks, Products based on } \\
\text { yoghurt, Products based on cheese, Ice cream, Cakes } \\
\text { and pastries, Candies, Chewing gum }\end{array}$ & Decision (EU) 2012/727 \\
\hline UV-treated milk & $\begin{array}{l}\text { Food resulting from new } \\
\text { production processes }\end{array}$ & $\begin{array}{l}\text { Pasteurised whole milk, } \\
\text { Pasteurised semi-skimmed milk }\end{array}$ & Decision (EU) 2016/1189 \\
\hline $\begin{array}{l}\text { Organic silicon } \\
\text { (monomethylsilanetriol } \\
\text { MMST) as source of } \\
\text { silicon }\end{array}$ & $\begin{array}{l}\text { Sources of vitamins, } \\
\text { minerals and other } \\
\text { substances }\end{array}$ & food supplements in liquid form & Decision (EU) 2016/1344 \\
\hline
\end{tabular}

in the Food Standards Code. A novel food is a non-traditional food that requires a public health and safety assessment with respect to: the potential for adverse effects on humans or the composition or structure of the food, the process by which the food was prepared, the source from which it was derived, the consumption patterns and quantities of the food, and other relevant aspects. Categories of novel foods may include plants or animals and their components, plant or animal extracts, herbs, including extracts, dietary macro-components, single chemical entities, microorganisms, including probiotics, foods produced from new sources, or by a process not previously applied to food. Additional considerations include whether a food is considered "traditional" or not. Non-traditional food means: a food not known for human consumption in Australia or New Zealand, a substance derived from a food if that substance is not known for human consumption in Australia or New Zealand unless it is a component of that food or another substance, or the source from which it is derived is not known for human consumption as a food in Australia or New Zealand.

Anyone wishing to sell a novel food or food ingredient must apply to Food Standards Australia New Zealand (FSANZ) to amend the standard to include the food or ingredient in the list.Foods that meet the definition of "novel food", including "novel food" ingredients, must be assessed for safety by FSANZ and listed in the table to Standard 1.5.1 before they can be marketed in Australia or New Zealand (Australia New Zealand Food Standards Code, 2017).

In Canada, novel foods are defined as foods/ingredients without a history of safe use as food in Canada, are produced by novel processes, or are derived from Genetically Modified Organisms (Guidelines for the Safety Assessment of Novel Foods, 2006). Before being placed on the market, novel foods require a pre-market assessment through Health Canada. The process consists of two stages of notification and review: a 45-day period for notification review and an additional 90 days if further information is requested to evaluate the novel food.

In China, novel foods and ingredients have been regulated since 1987. according to the Administrative Measures for Safety Review of New Food Materials (2017). Novel foods are the materials used for food processing and have no traditional eating habits in China. Novel foods include 
animal, plant, or micro- organisms or components extracted from these sources, food materials with structural changes, or newly developed food materials. Pre-market approval of novel food materials is conducted by the National Health and Family Planning Commission.

\section{CONSUMERS}

For several years now, the food sector has been facing an increasingly competitive and globalized market and more rigorous demand from consumers. This situation has forced food producers and food processors among other things, to innovate and develop new products to improve their position in the competition (Barrena and Sánchez, 2012). These novel foods are based on good scientific research, but their success in the market depends on how they are perceived by participants in the food supply chain, and consumers in particular. Technological change in food and food production can trigger a negative response among consumers, especially in the absence of good communication about risk assessment and cost-benefit efforts (Popa and Popa, 2012; Nauta et al, 2018). The success of novel foods depends largely on whether consumers are embracing these innovations. A large number of consumer's traditional food products still connects with a habit of life. When innovations are applied to Traditional food products (TFP) their degree of acceptance is strongly dependent on the product and on the type of innovation. In general, innovations that provide consumers with tangible and relevant benefits without producing substantial changes in the product are well accepted in TFP (packaging, nutritional, and innovations convenience oriented). However, and although they may be accepted, in some cases these innovations may damage the traditional character of the food (Guerrero et al., 2009). When novel foods are developed, the general public receives them with caution. People are often suspicious of these innovations. The adoption process requires time and depends on the social system of the country or region. In addition to nutritional value, food often has social and historical connotations, and in some instances may have religious significance (Asa, 2017). Depending on the region of the world, people often have different attitudes toward food. The acceptance of a technology depends on the consumer's perception of benefits and risks (Popa and Popa, 2012; Bearth and Siegrist, 2016; Connor and Siegrist, 2016). The motivation of the consumer to accept or reject these foods appears to be based on a range of mental traits, and product manufacturers consider individuals with specific, attitudes, expectations, values, and nutritional preferences during the development process. Familiar products are usually better liked than unfamiliar products (Tuorila and Hartmann, 2020). Insects and seaweeds are new constituents of the west that could potentially act as new sources of nutritious food (Belluco et al, 2007; Sogari et al., 2019; Alisha and Haider, 2019). These sources are widely used in Asia, however, the Western world has yet to accept these ingredients and adopt them into the everyday diet (Parelius, 2017; Mancini et al., 2019; Frigerio et al., 2020). Motives for the development of novel foods from the perspective of the consumers are organic, sensory properties, food variety, personalized nutrition, healthy eating, allergies intolerances, well being, ethical concerns, animal welfare, sustainable diets, and from the perspective of the industry are new resource, business profit, technological advances, extension of shelf life (Fig. 1) (Tuorila and Hartmann, 2020).

Many novel foods remain niche products, and consumers tend to reject certain types of novel foods that evoke disgust or lack naturalness (Tuorila and Hartmann, 2020; Parelius, 2017; Sidali et al., 2019). Novel food products developers must identify consumer expectations and factors that lead to consumer rejection at an early stage in product development. Recent trends have resulted in new or improved production, such as 3D printing technology, organic farming, and genetic modification (Tuorila and Hartmann, 2020). Although some consumers like the technological novelty, it encourages opposition from others. Further, the increased availability of unknown ethnic food to consumers offers diversity and new experiences (Tuorila and Hartmann, 2020). The applicability of the novel and innovative food packaging technique is greatly increasing due to health impacts, resulting in a reduced number of complaints by consumers. It is anticipated that in the near future traditional packaging will be replaced by innovative techniques of food packaging according to their development and spread on the global market (Majid et al., 2016). Consumer perceptions of the benefits associated with novel foods are also different. The perception of what represents both risk and benefit seems to be an important determinant of the acceptability of certain products and by

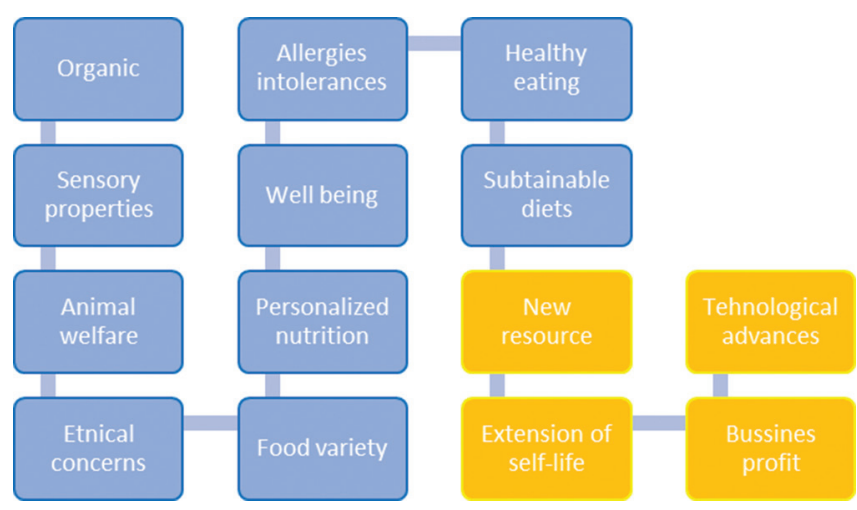

Fig 1. Motives for the development of novel foods from the perspective of the consumers (in blue) and the industry (in yellow) (Source: Tuorila \& Hartmann, 2020) 
consumers (Siegrist and Hartman, 2020). The full benefits of new food technologies will only be realized if consumers and food producers find them safe and beneficial (Popa and Popa, 2012). It is generally established that the levels of acceptance of insects as human food are low (Schösler et al., 2012; Vanonhacker et al.; 2013, Verbeke, 2015) and the general reluctance to consume of Westerners to consume insects or insect-based foods (Hartmann et al., 2015; Ruby et al., 2015). Consumer education is very important for the acceptance of new food, and the social acceptance for these new foods is higher when consumers had experience with food and when they are incorporated into familiar food items (Santeramo et al., 2018).

\section{CONCLUSION}

In order to contribute to consumer health, government agencies around the world have established some premarket approval procedures for novel foods. These procedures vary from market to market. The European Union has clearly regulated the labeling of novel foods. The European Food Safety Authority (EFSA) first conducts a scientific risk assessment for each new food application. The European Commission is responsible for issuing a Novel Food that is found to be safe. Australia has also clearly regulated the labeling of Novel Foods. In the US, they are regulated as direct food additives or food contact materials, depending on their use. An increasingly stringent requirement for sustainability in food consumption, is driving the search for new food sources. Consumers can benefit from novel foods that meet specific nutritional needs, offer variety and convenience, and meet ethical and sustainable consumption requirements.

\section{AUTHORS' CONTRIBUTIONS}

Knežević N.: Conceptualization, Study of regulations, Manuscript review; Grbavac S.: Study of regulations, Drafted the manuscript; Palfi M.: Review design, Study of regulations; Badanjak Sabolović M.: Study of regulations; Rimac Brnčić, S.: Conceptualization, Study of regulations, Review design. All authors revised the document critically and approved the final manuscript for submission to the Journal.

\section{REFERENCES}

Abdelmoteleb, M., C. Zhang, B. Furey, M. Kozubal, H. Griffiths, M. Champeaud and R. E. Goodman. 2021. Evaluating potential risks of food allergy of novel food sources based on comparison of proteins predicted from genomes and compared to www. AllergenOnline.org. Food Chem. Toxicol. 147: 111888.

Adams, R. C., J. Sedgmond, L. Maizey, C. D. Chambers and N. S.
Lawrence. 2019. Food addiction: Implications for the diagnosis and treatment of overeating. Nutrients. 11: 2086.

Administrative Measures for Safety Review of New Food Materials. 2017. Available from: http://www.lawinfochina.com/display. aspx?id=28054\&lib=law. [Last accessed on 2020 Oct 20].

Alisha, R. P. D. and A. Haider. 2019. Seaweed: Nutritional and health benefits. Pharm. Innov. J. 8: 80-83.

Asa, R. S. 2017. Malaysian halal certification: It's religious significance and economic value. J. Syariah. 25: 137-156.

Australia New Zealand Food Standards Code. 2017. Standard 1.5.1 Novel Foods. F2017C00324. 2017. Available from: https://www. legislation.gov.au/Series/F2015L00403. [Last accessed on 2020 Jul 21].

Baraniak, J., R. Kujawski and M. Ożarowski. 2016. Law regulations concerning food supplements, dietetic food and novel food containing herbal substances. Herba Pol. 62: 97-107.

Barrena, R. and M. Sánchez. 2012. Neophobia, personal consumer values and novel food acceptance. Food Qual. Prefer. 27: 72-84.

Bearth, A. and M. Siegrist. 2016. Are risk or benefit perceptions more important for public acceptance of innovative food technologies: A meta-analysis. Trends Food Sci. Technol. 49: 14-23.

Belluco, S., A. Halloran and A. Ricci. 2017. New protein sources and food legislation: the case of edible insects and EU law. Food Secur. 9: 803-814.

Blaauboer, B. J., A. R. Boobis, B. Bradford, A. Cockburn, A. Constable, M. Daneshian, G. Edwards, J. A. Garthoff, B. Jeffery, C. Krul and J. Schuermans. 2016. Considering new methodologies in strategies for safety assessment of foods and food ingredients. Food Chem. Toxicol. 91: 19-35.

Caporgno, M. P. and A. Mathys. 2018. Trends in microalgae incorporation into innovative food products with potential health benefits. Front. Nutr. 5: 58.

Cappelli, A., N. Oliva, G. Bonaccorsi, C. Lorini and E. Cini. 2020. Assessment of the rheological properties and bread characteristics obtained by innovative protein sources (Cicer arietinum, Acheta domesticus, Tenebrio molitor): Novel food or potential improvers for wheat flour? Lwt. 118: 108867.

Commission Implementing Regulation. (2018) (EU) 2018/460 of 20 March 2018 Authorising the Placing on the Market of Ecklonia cava Phlorotannins as a Novel Food under Regulation (EU) 2015/2283 of the European Parliament and of the Council and amending Commission Implementing Regulation (EU) 2017/2470. 2018. Official Journal of the European Union. L 78/2.

Commission Implementing Regulation. (2018) (EU) 2018/462 of 20 March 2018 Authorising an Extension of Use of L-ergothioneine as a Novel Food under Regulation (EU) 2015/2283 of the European Parliament and of the Council, and amending Commission Implementing Regulation (EU) 2017/2470. 2018. Official Journal of the European Union. L 78/11.

Commission Implementing Regulation. (2020) (EU) 2020/1163 of 6 August 2020 Authorising the Placing on the Market of Vitamin D2 Mushroom Powder as a Novel Food under Regulation (EU) 2015/2283 of the European Parliament and of the Council and amending Commission Implementing Regulation (EU) 2017/2470. Official Journal of the European Union. L 258/1.

Commission Implementing Decision. 2012. Commission Implementing Decision of 22 November 2012 Authorising the Placing on the Market of Bovine Lactoferrin as a Novel Food Ingredient under Regulation (EC) No 258/97 of the European Parliament and of the Council (FrieslandCampina). 2012. Official Journal of the European Union. L 327/52.

Commission Implementing Decision. (2016) (EU) 2016/1189 of 19 
July 2016 Authorising the Placing on the Market of UV-Treated Milk as a Novel Food under Regulation (EC) No 258/97 of the European Parliament and of the Council. 2016. Official Journal of the European Union. L 196/50.

Commission Implementing Decision. (2016) (EU) 2016/1344 of 4 August 2016 Authorising the Placing on the Market of Organic Silicon (Monomethylsilanetriol) as a Novel Food Ingredient under Regulation (EC) No 258/97 of the European Parliament and of the Council. 2016. Official Journal of the European Union. L 213/12.

Connor, M. and M. Siegrist. 2016. The stability of risk and benefit perceptions: A longitudinal study assessing the perception of biotechnology. J. Risk Res. 19: 461-475.

De Boer, A. and A. Bast. 2018. Demanding safe foods-safety testing under the novel food regulation (2015/2283). Trends Food Sci. Technol. 72: 125-133.

De Roos, B., Bronze, Aura, A. M. Cassidy, A. Garcia Conesa, M. T. Gibney, E. R. Greyling, A. Kaput, J. Kerem, Z. Knežević, N. Kroon, P. Landberg, R. Manach, C. Milenkovic, D. RodriguezMateos and A. Tomás-Barberán, F. A. 2019. Targeting the delivery of dietary plant bioactives to those who would benefit most: from science to practical applications. Eur. J. Nutr. 58: 65-73.

European Commission. (2020) Novel Food. Available from: https:// www.ec.europa.eu/food/safety/novel_food_en. [Last accessed on 2020 May 20].

Food and Drug administration. (2020) Department of Health and Human Services, Subchapter B-Food for Human Consumption, Part 170-Food Additives. Available from: https://www.ecfr. gov/cgi-bin/text-idx?SID=2c45815199b7dc482efbfc941302b ce6\&mc=true\&tpl=/ecfrbrowse/Title21/21cfrv3_02.tpl\#0. [Last accessed on 2020 Jun 23].

Guidelines for the Safety Assessment of Novel Foods. 2020. Available from: https://www.canada.ca/en/health-canada/services/foodnutrition/legislation-guidelines/guidance-documents/guidelinessafety-assessment-novel-foods-derived-plants-microorganisms/ guidelines-safety-assessment-novel-foods-2006.html. [Last accessed on 2020 Oct 22].

Frigerio, J., G. Agostinetto, A. Galimberti, F. De Mattia, M. Labra and A. Bruno. 2020. Tasting the differences: Microbiota analysis of different insect-based novel food. Food Res. Int. 137: 109426.

Guerrero, L., M. D. Guàrdia, J. Xicola, W. Verbeke, F. Vanhonacker, S. Zakowska-Biemans, M. Sajdakowska, C. Sulmont-Rosse, S. Issanchou, M. Contel, M. L. Scalvedi, B. S. Granli and M. Hersleth. 2009. Consumer-driven definition of traditional food products and innovation in traditional foods. A qualitative crosscultural study. Appetite. 52: 345-354.

Hartmann, C., J. Shi, A. Giusto and M. Siegrist. 2015. The psychology of eating insects: A cross-cultural comparison between Germany and China. Food Qual. Prefer. 44: 148-156.

House, J. 2019. Insects are not 'the new sushi': Theories of practice and the acceptance of novel foods. Soc. Cult. Geogr. 20: 12851306.

Kant, A. K. 2010. Dietary patterns: Biomarkers and chronic disease risk. Appl. Physiol. Nutr. Metab. 35: 199-206.

Kaur, K., G. Allahbadia and M. Singh. 2018. Utilizing microalgae addition in novel food products which might improve health a review. Nutrients. 3: 1-15.

Knežević, N., M. Šćetar and K. Galić. 2012. Possibilities of nanotechnology application in the food sector with reference on its consumers acceptance. Hrvat. Časop. Prehram. Tehnol. Biotehnol. Nutr. 7: 126-131.

Laureati, M., C. Proserpio, C. Jucker and S. Savoldelli. 2016. New sustainable protein sources: Consumers' willingness to adopt insects as feed and food. Ital. J. Food Sci. 28: 652-668.

Magnuson, B., I. Munro, P. Abbot, N. Baldwin, R. Lopez-Garcia, K. Ly, L. McGirr, A. Roberts and S. Socolovsky. 2013. Review of the regulation and safety assessment of food substances in various countries and jurisdictions. Food Addit. Contam. Part A. 30: 1147-1220.

Majid, I., G. A. Nayik, S. M. Dar and V. Nanda. 2018. Novel food packaging technologies: Innovations and future prospective. J. Saudi Soc. Agric. Sci. 17: 454-462.

Mancini, S., R. Moruzzo, F. Riccioli and G. Paci. 2019. European consumers' readiness to adopt insects as food. A review. Food Res. Int. 122: 661-678.

Martini, D., C. Del Bo' and A. Cavaliere. 2019. Current Legislation in the European Context: A Focus on Food Labeling, Novel Foods, Nutrition, and Health Claims. In: D. Bagchi (Ed.), Nutraceutical and Functional Food Regulations in the United States and around the World. Academic Press, Cambridge, MA, USA, pp. 253-265.

Mazzucchelli, G., T. Holzhauser, T. Cirkovic Velickovic, A. DiazPerales, E. Molina, P. Roncada, P. Rodrigues, K. Verhoeckx and K.Hoffmann-Sommergruber. 2018. Current (food) allergenic risk assessment: Is it fit for novel foods? Status quo and identification of gaps. Mol. Nutr. Food Res. 62: 1700278.

Nauta, M. J., R. Andersen, K. Pilegaard, S. M. Pires, G. Ravn-Haren, I. Tetens and M. Poulsen. 2018. Meeting the challenges in the development of risk-benefit assessment of foods. Trends Food Sci. Technol. 76: 90-100.

Overview of International Regulatory Approaches Proposal P1024. 2020. Available from: https://www.foodstandards.gov.au/code/ proposals/Pages/P1024.aspx. [Last accessed on 2020 Jun 16].

Novel Foods Authorisation Guidance. 2020. Available from: https:// www.food.gov.uk/business-guidance/regulated-products/novelfoods-guidance. [Last accessed on 2021 Jan 04].

Parelius, J. 2017. Packing of Novel Food. How Can Packaging Break Barriers through Influencing Consumer Perception? Available from: https://www.ntnu.edu/docu ments/139799/1279149990/24+Article+Final_johannep_ fors\%C3\%B8k_2017-12-08-00-25-19_TPD4505.johanne. parelius.pdf/c5bca01b-266b-44a9-8abd-f73130444412. [Last accessed on 2020 Aug 31].

Popa, M. E. and A. Popa. 2012. Consumer behavior: Determinants and trends in novel food choice. In: A. McElhatton and do Amara Sobral (Eds.), Novel Technologies in Food Science. Springer, New York, pp. 137-156.

Regulation (EC) No 258/97. 1997. European Parliament and of the Council of 27 January 1997 Concerning Novel Foods and Novel Food Ingredients. Official Journal L, No. 043.

Regulation (EU) 2015/2283. 2015. European Parliament and of the Council of 25 November 2015 on Novel Foods, Amending Regulation (EU) No 1169/2011 of the European Parliament and of the Council and Repealing Regulation (EC) No 258/97 of the European Parliament and of the Council and Commission Regulation (EC) No 1852/2001. Official Journal of the European Union. L 327/1.

Ruby, M. B., P. Rozin and C. Chan. 2015. Determinants of willingness to eat insect in the USA and India. J. Insects as Food Feed. 1 : 215-225.

Santeramo, F. G., D. Carlucci, B. De Devitiis, A. Seccia, A. Stasi, R. Viscecchia and G. Nardone. 2018. Emerging trends in European food, diets and food industry. Food Res. Int. 104: 39-47.

Shao, A., A. Drewnowski, D. C. Willcox, L. Krämer, C. Lausted, M. Eggersdorfer, J. Mathers, J. D. Bell, R. K. Randolph, R. Witkamp 
and J. C. Griffiths. 2017. Optimal nutrition and the ever-changing dietary landscape: A conference report. Eur. J. Nutr. 56: 1-21.

Sidali, K. L., S. Pizzo, E. I. Garrido-Pérez and G. Schamel. 2019. Between food delicacies and food taboos: A structural equation model to assess Western students' acceptance of Amazonian insect food. Food Res. Int. 115: 83-89.

Siegrist, M. and C. Hartmann. 2020. Consumer acceptance of novel food technologies. Nat. Food. 1: 343-350.

Sogari, G., D. Bogueva and D. Marinova. 2019. Australian consumers' response to insects as food. Agriculture. 9: 108.

Schösler, H., J. de Boer and J. Boersema. 2012. Can we cut out the meat of the dish? Constructing consumer-oriented pathways towards meat substitution. Appetite. 58: 39-47.

Tuorila, H. and C. Hartmann. 2020. Consumer responses to novel and unfamiliar foods. Curr. Opin. Food Sci. 33: 1-8.
Vanonhacker, F., E. J. van Loo, X. Gellnyck and W. Verbeke. 2013. Flemish consumer attitudes towards more sustainable food choices. Appetite. 62: 7-16.

Verbeke, W. 2015. Profiling consumers who are ready to adopt insects as a meat substitute in a Western society. Food Qual. Prefer. 39: 147-155.

Ververis, E., R. Ackerl, D. Azzollini, P. A. Colombo, A. de Sesmaisons, C. Dumasa, A. Fernandez-Dumonta, L. Ferreira da Costaa, A. Germinia, T. Goumperisa, E. Koulouraa, L. Matijevica, G. Precupa, R. Roldan-Torresa, A. Rossia, R. Svejstila, E. Turlaa and W. Gelbmann. 2020. Novel foods in the European Union: Scientific requirements and challenges of the risk assessment process by the European Food Safety Authority. Food Res. Int. 137: 109515.

Zarbà, C., G. Chinnici and M. D’Amico. 2020. Novel Food: The impact of innovation on the paths of the traditional food chain. Sustainability. 12: 555. 